\title{
Elektron mühitdə pasiyentlərin fərdi məlumatlarının mühafizəsinin aktual problemləri
}

\author{
Kəmalə Qurbanova \\ AMEA İnformasiya Texnologiyaları İnstitutu, Bak1, Azərbaycan \\ kemalewamil@gmail.com
}

\begin{abstract}
Xülaso - İşdə pasiyentlərin fordi məlumatlarının yayılmasına imkan yaradan informasiya-kommunikasiya texnologiyalarının tibb sahələrinə tətbiqi araşdırılmışdır. Tibbi informasiya sistemlərinin və Internet mühitində tibbi sosial medianın yaratdığı problemlər şərh edilmişdir. Elektron mühitdə tibbin normativ-hüquqi bazasının formalaşdırılması, proqram-texniki bazasının təkmilləşdirilməsi, peşəkar kadrların hazırlanması və təhlükəsizliyin təmin olunması üçün yeni texnologiyaların işlənməsi tövsiyə olunmuşdur.
\end{abstract}

Açar sözlor-tibbi informasiya sistemlori; tibbi sosial media; moxfi molumatlar; fordi molumatların tohlükosizliyi

\section{GIRIŞ}

Son illərdə Informasiya-Kommunikasiya Texnologiyalarının (İKT) səhiyyəyə nüfuz etməsi nəticəsində tibbi informasiya sistemləri (TÍS) və tibbi sosial media (TSM) yaranmışdır. IKKT-nin tibb sahəsinə kütləvi şəkildə tətbiq olunması elektron mühitdə pasiyentlərin fərdi məlumatlarının mühafizəsini aktual etmişdir.

TİS-in təkmilləşdirilməsi səhiyyənin inkişafının strateji istiqamətlərindən biridir. TİS xəstə və ona göstərilən bütün xidmətlər haqqında qeydlərin aparılmasını təmin edir. Pasiyentlərin fərdi məlumatlarının toplandığı TİS tibb işçilərinin informasiya əldə etmək üçün müraciət etdiyi mənbədir. $\mathrm{Bu}$ sistemin yaranması həkim və tibb bacılarına pasiyentlərin kliniki vəziyyəti ilə bağlı qərar qəbul etməsinə yardım edir. TIS-in digər proqram məhsullarından əsas fərqi Şəxsi və məxfi məlumatları saxlaması və emal etməsidir. Bu tip məlumat bazalarında bəzən insanların həyatının asılı ola biləcəyi kritik məlumatlar mövcud olur.

Bundan əlavə Internetin yaratdı ̆̆ imkanlar müxtəlif peşəkar sahələr kimi həkim və pasiyentlərin sosiallaşdığı tibbi vertual mühütin və tibbi şəbəkələrin də inkişafına səbəb olmuşdur. Pasiyentlər sosial media resurslarından istifadə etməklə: sağlamlıqları, xəstəlikləri ilə əlaqədar məlumatlar əldə edə bilərlər; müəyyən xəstəliyin müalicəsi ilə bağlı təcrübələrini bölüşə bilərlər; həkimlər haqqında məlumat əldə edə bilərlər; həkimlər ilə əlaqə saxlayıb məsləhət və tövsiyə ala bilərlər. Sosial media pasiyentlərlə yanaşı, həkimlər üçün də geniş imkanlar yaratmışdır. Hazırda sosial mediadan istifadə edən həkimlər: iş yerini tərk etmədən konsilium və konfransları izləmək; həmkarları ilə maraqlı diskusiyalar keçirmək; tibb bacılarına kliniki vəziyyətlərdə qərar qəbul etməkdə dəstək olmaq; şəxsi potensialını yüksəltmək üçün peşəkar heyət yı̆̆maq və s. kimi imkanlar əldə edirlər [1].

Digər tərəfdən TSM hər kəs üçün açıq və əlçatan olduğundan pasiyentlərin fərdi məlumatlarının məxfiliyi və təhlükəsizliyi üçün potensial təhdidlərə yol açır. Beləliklə, TİS ilə yanaşı TSM də pasiyentlərin fərdi məlumatlarının təhlükə mənbəyinə çevrilir. Ona görə də, avtomatlaşdırılmış informasiya sistemlərində və müxtəlif tibbi sosial şəbəkələrdə vətəndaşların fərdi məlumatlarının qorunması vacibdir.

\section{TİBBİ İNFORMASIYA SİSTEMLӘRINDD FӘRDİ MOLUMATLARIN QORUNMASI PROBLEMLORİ}

TİS tibb müəssisələrinin tibbi, inzibati, təsərrüfat və digər fəaliyyətini əhatə edən proseslərin və prosedurların kağız daşıyıcılardan elektron informasiya sisteminə keçirilməsi vasitəsi ilə daha dəqiq təqib olunması, analitik və hesabat məlumatlarının operativ əldə olunması, uzun müddət ərzində toplanan məlumatların arxivləşdirilməsi, istənilən zaman vətəndaşların tibbi müayinə və müalicə məlumatlarının operativ şəkildə əldə olunmasına imkan yaradır [2].

E-tibbin yaradılması bir sıra əsas istiqamətlər üzrə əhəmiyyətli nəticələrin əldə olunmasını nəzərdə tutur: elektron tibb kartlarının tətbiqi, qeydiyyat işinin aparılmasının avtomatlaşdırılması, sənədləşmə və arxivləşdirmənin elektron formada aparılması, həkimin iş yerinin kompüterləşdirilməsi, pasiyentin və menecerin şəxsi kabineti, rəqəmsal resept, teletibbin inkişafi, səhiyyə sistemində vahid informasiya fəzasının yaradılması, o cümlədən əhalinin sağlamlıq vəziyyəti, epidemioloji sağlamlığının monitorinqi sistemlərinin inkişafi və s. elekton tibbin tətbiqi istiqamotlərindəndir. Pasiyentin elektron tibb kartı və ya elektron sağlamlıq kartı onun doğum günündən başlayaraq doldurulur və bu proses onun bütün həyatı boyu davam edir [3]. Fərdi məlumatların toplandığ elektron tibb kartı e-tibbin baza elementidir.

Dünya praktikasına görə də, TİS-də informasiya təhlükəsizliyi, məlumatların məxfiliyi, bütövlüyü və tamlığı təmin olunmalı və yalnız səlahiyyətli şəxslərin məlumatlara girişi mümkün olmalıdır. Təəssüf ki, bəzən şəxsi məlumatlardan yalnız xeyirxah məqsədlər üçün deyil, həm də fərdin, cəmiyyətin və dövlətin mənafeyinə zərər vurmaq üçün istifadə edilir. Buna görə də, səhiyyə sistemində informasiya təhlükəsizliyinin əhəmiyyəti son dərəcədə artır və ön plana çıxır $[4,5]$. 


\section{“Informasiya tohlükosizliyinin aktual multidissiplinar elmi-praktiki problemlori” \\ V respublika konfransı, 29 noyabr 2019-cu il}

Qanuni olaraq, xəstələr haqqında tibbi məlumatlar peşəkar sirri təşkil edən məlumatlara aiddir. Buna görə də, TİS-də həm fərdi məlumatların, həm də bütövlükdə informasiya sisteminin təhlükəsizliyini təmin etmək üçün bir sıra tədbirlər həyata keçirilməlidir, əks halda TISS-in istifadəsi qanunsuzdur.

Məlumatların təhlükəsizliyini və məxfiliyini təmin etmək müasir TİS-in istismarçılarına qoyulan əsas şərtlərindən biridir. $\mathrm{Bu}$ tələbin informasiya-kommunikasiya və hesablama sistemlərinə tətbiqi təxirəsalınmaz vəzifədir [6].

TİS-də fərdi məlumatların qorunması prosesindəki əsas problemlər aşağıdakılardır [7]:

- İnformasiyanın itkisi, təhrif olunması və saxtalaşdırılmasının qarşısının alınması;

- fərdin, cəmiyyətin və dövlətin məlumatlarının təhlükəsizliyinə təhdidlərin qarşısının alınması;

- məlumatı silmək, dəyişdirmək, təhrif etmək və surətini çıxarmaq üçün icazəsiz hərəkətlərin qarşısının alınması;

- informasiya mənbələri və sistemlərinə müxtəlif qanunsuz müdaxilələrin qarşısının alınması;

- sənədləşdirilmiş məlumatların mülkiyyət obyekti kimi istifadəsinin qanuni rejiminin təmin edilməsi;

- vətəndaşların konstitusiya hüququ ilə informasiya sistemlərində mövcud olan fərdi məlumatların məxfiliyinin qorunmas1;

- informasiya sistemlərinin istismarı və tətbiqi sahəsində subyektlərin hüquqlarının təminatı.

Göründüyü kimi, TİS-də fərdi məlumatların qorunması məsələsinin iki aspekti təmsil olunur. Bunlardan birincisi, xəstələrin fərdi məlumatlarının qorunması haqqında qanunla tənzimlənən həkimlə xəstənin qarşılıqlı əlaqəsinin etik (peşəkar)

tərəfidir. İkinci aspekt tibbi sistemdəki məlumatların texniki baxımdan qorunmasıdır, yəni məlumat sisteminin proqramaparat kompleksi daxilində adekvat məlumat qoruma mexanizmlərinin yaradılmasıdır [7].

\section{TİBBİ SOSİAL MEDİADA FORDİ MOLUMATLARIN YAYILMASI}

İnternet böyük imkanlar təqdim edən güclü alətdir və son bir neçə onillikdə onun geniş istifadəsi sayəsində insanları, təşkilatları və dövlətləri birləşdirən, onları bir-birindən qarşılıqlı asılı edən qlobal kiberfəza formalaşmışdır. Real həyatda mövcud olan mənfi elementlər kiberfəzaya proyeksiyalanır və spamlar, viruslar, fərdi məlumatların ələ keçirilməsi, kibercinayətkarlıq, kiberterrorizm, kibermüharibə kimi təhdidlər yaranır [8].

Sosial şəbəkələrdən kütləvi surətdə istifadə olunması Internet mühitində TSM-nın meydana gəlməsinə səbəb olmuşdur. Müxtəlif tibbi virtual qruplarda, bloklarda və şəbəkələrdə sosiallaşan insanlar şəxsi təcrübələrini, biliklərini, əldə etdiyi nailiyyətləri bölüşür, hər hansı bir probleminin həll olmasında yardım edən insanlarla sevincini paylaşır, yaxud da məsləhət almaq məqsədilə şəxsi problemlərinin həlli üçün vacib suallarla müraciət edirlər. Tibb işçiləri, həkimlər sualları cavablandıraraq öz peşəkarlığını nümayiş etdirir və pasiyentlərlə qarş1lıqlı ünsiyyətdə olmaq üçün virtual mühitdən istifadə edirlər. İnsanlar isə bu və ya digər həkimlərin müalicə metodu, təcrübəsi, əldə etdiyi nəticələr, müəssisədə tibbi xidmətin keyfiyyəti, müasir və yüksək dəqiqliyə malik avadanlıqlarla təhcizatı, pasiyent təhlükəsizliyi və s. ilə tanış olur, probleminin həlli üçün hansı xəstəxanaya və kimə müraciət edəcəyini dəqiqləşdirir. Qənaətbəxş nəticə əldə etməyən pasiyentlər xidmətindən narazı olduğu xəstəxanalar, müalicə metodu düzgün olmayan həkimlər, keyfiyyətisiz dərman vasitələri, və digər çatışmazlıqlar ilə bağlı məlumatı sosial şəbəkədə yerləşdirirlər. $\mathrm{Bu}$ fərdi məlumatların yayılmasının humanizm tərəfi bütün pasiyentlərin mövcud durumdan bəhrələnməsidir. Lakin, bəzən məlumatlar qərəzli (reklam və ya antireklam) şəklində təhrif olunur. Göründüyü kimi, TSM-da fərdi məlumatların hamı tərəfindən əlçatan olmasının həm mənfi, həm müsbət tərəfləri vardır.

Hal-hazırda tibbi şəbəkələrdə həkimlərə müraciətlər zamanı nəinki pasiyentlərin fərdi məlumatları, hətta onların sorğularını cavablandıran həkimlərin verdiyi məsləhət, təyin etdiyi diaqnoz, müalicə üsulu və s. də şəbəkələrdə hər kəsə açıq və əlyetən olur. Bu da onların fərdi, sağlamlıq vəziyyəti ilə bağlı məlumatlarının konfidensiallığı üçün təhlükə yaradır [9].

$\mathrm{Bu}$ problemin aradan qaldırılması üçün 80-dən çox tibb ixtisasını və 18 mindən çox həkimi əhatə edən "healthcaremagic.com" tibbi sosial şəbəkəsinin təhlükəsizlik siyasətindən yararlanmaq olar. Bu şəbəkədə pasiyentlər həkimlərə müraciət edərkən cavablar onların e-mail ünvanına göndərilir. doslovno.com və health.mail.ru şəbəkələrində isə pasiyentlər qeydiyyatdan keçərkən adı, yaşı, yaşadığı ərazi, email ünvanı ilə bağlı göstərdikləri fərdi məlumatların konfidensiallığının təmin edilməsi məqsədilə sorğuların və həkim cavabının "hər kəsə açıq" olub-olmaması ilə bağlı onların rəyi öyrənilir [10].

\section{NəTİCə}

Hal-hazırda qloballaşan dünyamızda günbəgün inkişaf edən İKT-nin tibb sahəsinə də tətbiqi təbii prosesdir. Aparılmış araşdırmalar göstərir ki, TIS və TSM həkim-pasiyent münasibətlərində vacib amilə çevrilmişdir. Lakin, TIS-in səhiyyənin inkafinda əvəzolunmaz faydası olmasına baxmayaraq qeyri- peşəkar istifadəçilər tərəfindən fərdi məlumatların təhrif olunmasına və TSM istifadəçilərinin sayının fasiləsiz artması isə fərdi məlumatların yayılmasına səbəb olur.

$\mathrm{Bu}$ baxımdan elektron mühitdə tibbin normativ-hüquqi bazasının formalaşdırılması, proqram-texniki bazasınn təkmilləşdirilməsi, peşəkar kadrların hazırlanması, fərdi tibbi məlumatların online mühitdə təhlükəsizliyinin təmin olunması istiqamətində yeni texnologiyaların və proqram təminatının formalaşması məsələlərinin araşdırılması zəruridir. 


\section{“Informasiya tohlükosizliyinin aktual multidissiplinar elmi-praktiki problemlori” V respublika konfransı, 29 noyabr 2019-cu il}

\section{İSTINADLAR}

[1] M.H. Məmmədova, A.M. İsayeva, "Sosial media mühitində e-tibb fəaliyyəti”, İnformasiya cəmiyyəti problemləri, 2018, №1, s.57-68.

[2] Nümunəvi tibbi-informasiya sistemi, http://esehiyye.gov.az/az/s/9/N\%C3\%BCmun\%C $\% \% 99 v i+t i b b i-$ informasiya+sistemi

[3] Elektron tibb sağlamlığın qorunması məqsədilə İKT-dən istifadəni nəzərdə tutur, https://ict.az/az/news/694/

[4] А.П. Бирюков, Е.В. Васильев, С.М. Думанский, О.А. Тихонова, Ю.А. Герт, Н.В. Капитонова, "Выбор компьютерных технологий для аналитической поддержки базы данных крупномасштабных медицинских информационных систем", Саратовский научномедицинский журнал, 2013, № 9(4), с.983-987.

[5] В.В. Домарев, “Защита информации в медицинских информационных системах: врачебная тайна и современные информационные технологии”, Клиническая информатика и телемедицина, 2004, .№1(2), с.147-154.

[6] Я.И. Гулиев, И.А. Фохт, О.А. Фохт, А.Ю. Белякин, “Медицинские информационные системы и информационная безопасность. Проблемы и решения", Программные системы: теория и приложения: тр. междунар. конф. Переславль-Залесский, 2009, c. $175-206$.

[7] М.К. Карабаев, А.А. Абдуманонов “Алгоритмы и технологии обеспечения безопасности информации в медицинской информационной системе ExterNET”, Программные продукты и системы 2013, №(1), с.150-155.

[8] Н.В. Юргель, Е.Л. Никонов, И.В. Гармаш, Л.Ю. Мерзлов, И.Г. Поздняков, "Защита информации в регистре медицинских и фармацевтических работников”, Вестник Росздравнадзора, 2008, № (1), c.75-76.

[9] Y.N. İmamverdiyev "İnformasiya təhlükəsizliyi üzrə beynəlxalq koalisiya modeli”, İnformasiya cəmiyyəti problemləri, 2019, №1, s.1420.

[10] M.H. Məmmədova, Z.Q.Cəbrayılova, A.M. İsayeva "Sosial media mühitinin həkim-pasiyent münasibətləri seqmentinin analizi: imkanlar və problemlər", İnformasiya cəmiyyəti problemləri, 2019, №2, s.41-50.

\section{ACTUAL PROBLEMS OF PROTECTION OF PATIENTS PERSONAL DATA IN ELECTRNIC ENVIRONMENT}

Kamala Gurbanova

Institute of Information Technology of ANAS, Baku, Azerbaijan kemalewamil@gmail.com

Abstract- The study investigates the application of information and communication technologies which allows the dissemination of personal information of patients to medical fields. The problems posed by medical information systems and medical social media in the Internet environment have been explained. It is recommended to create a legal framework for medicine in the electronic environment, to improve the software and hardware, to create a proffesional staff and to develop new technologies to ensure security.

Keywords- medical information systems; medical social media; confidential information; personal data security 